\title{
Partial Trisomy in a Child with Features Suggesting Mongolism
}

\author{
H. K. KUMBNANI and R. A. PFEIFFER
}

From the Institute of Human Genetics, Wilhelms-Universität Münster, Western Germany

In 1963 Warkany and Soukup described a girl with certain features of mongolism, but the diagnosis was never considered to be established. She was found to be the carrier of a non-familial chromosomal abnormality which could be explained as partial trisomy-21. The authors, however, did not exclude the possibility that they were dealing with a syndrome 'differing from mongolism clinically and cytogenetically'.

A similar anomaly, a long acrocentric autosome replacing one chromosome of group $G$, has been found in true mongols, and was interpreted as a 'translocation en tandem' by Lejeune et al. (1965). We wish to report another case which indicates the difficulty of interpreting sporadic structural aberrations.

\section{Case History}

This infant, born on May 1, 1967, was regarded as an unusual case of mongolism by several experienced paediatricians. She was the only child of healthy parents without any history of preconceptual radiation. At her birth the father was aged 29, the mother 25 . The mother had had mumps during the 3rd month of pregnancy. Her birthweight at term was $2500 \mathrm{~g}$., her length $50 \mathrm{~cm}$. At the age of 7 months she was a well-nourished infant but her psychomotor development was clearly retarded. Facially, she resembles Asiatic babies with Down's syndrome (Fig. 1). The anterior fontanelle and cranial sutures were wide open, the head circumference being $40 \mathrm{~cm}$. On the tip of the short nose was a haemangioma. Slight oedema was present on the back of the hands and feet, and the fingers were fusiform. The toe-nails were missing (Fig. 2). $X$-rays confirmed brachycephaly with nearly vertical basis of the skull; the ossification was retarded. There was no brachymesophalangy of the little finger. All distal and most of the middle phalanges of the feet, however, were absent. The iliac index was 68. The electroencephalogram did not show gross abnormal features. These findings as well as the dermatoglyphs (Fig. 3) do not support a diagnosis of mongolism.

Received July 4, 1968.

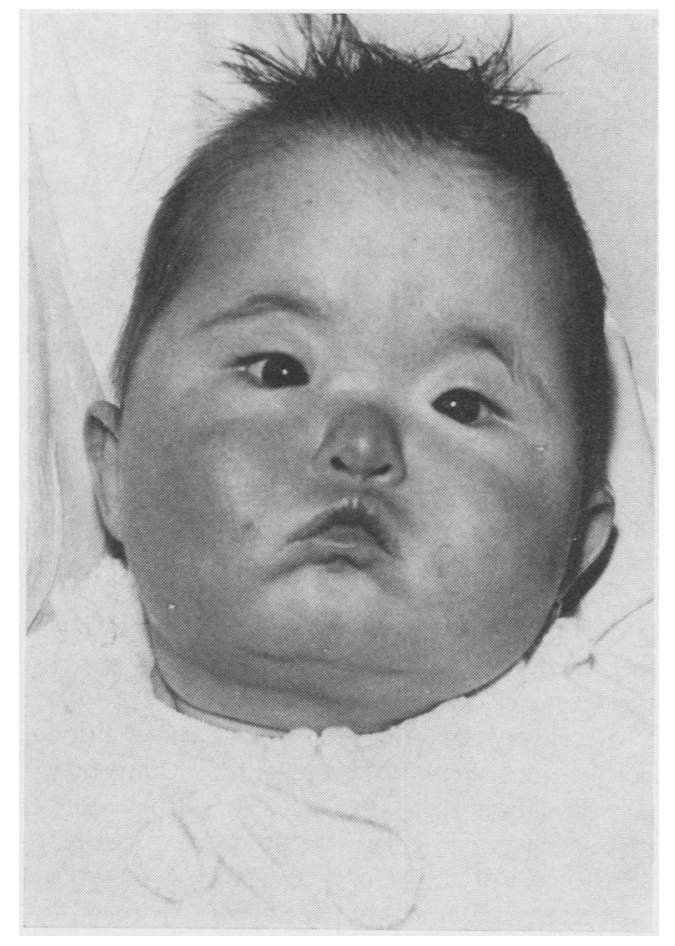

FIG. 1. The propositus aged 7 months.

\section{Cytogenetic Studies}

The karyotypes of the child and her parents were studied from lymphocytes (Moorhead et al., 1960). Autoradiography was performed after continuous incorporation of ${ }^{3} \mathrm{H}$-thymidine for the final $6 \frac{1}{2}$ hours of the culture $(1 \mu \mathrm{Ci} / \mathrm{ml}$.). Photosensitive emulsion Ilford $\mathrm{K} 2$ was used. Slides were exposed for 3-6 weeks. After photography of well-labelled cells the silver grains were removed with Farmer's solution.

\section{Results}

Counts were made of 20 cells of each of the parents and 30 cells of the propositus. The karyotypes of the parents were normal. The modal number of the 


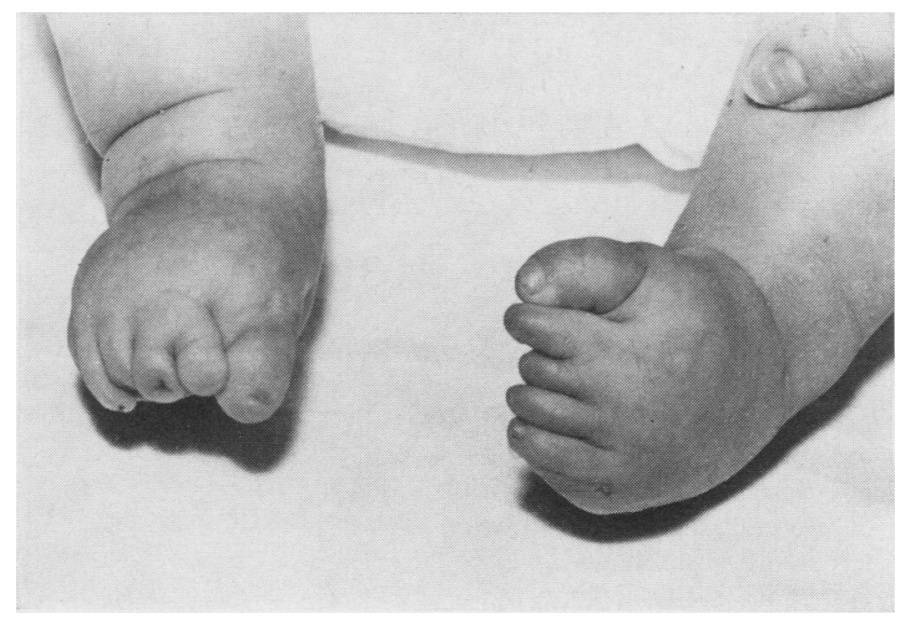

FIG. 2. Partial aplasia of the toes and nails.

child's chromosomes was 46 ; one chromosome of the $G$ group was missing, while another large acrocentric chromosome with satellites on the short arms was consistently seen. Since it could be paired with the D group autosomes (Fig. 4a), the D and $\mathrm{G}$ chromosomes of 51 cells were analysed after autoradiography. The labelling pattern of the D group chromosomes was compatible with qualitative and semiquantitative data from our laboratory (Büchner, Wilkens, and Pfeiffer, 1968). The labelling differences between the 3 remaining $G$ chromosomes, however, were inconclusive as to which pair the missing chromosome belongs to. In most cells the distal portion of the long arm of the extra chromosomes seems to replicate later than the proximal part (Fig. 4b). We are, therefore, unable to decide whether the translocated segment is fused with the end of the $G$ chromosome or inserted near the centromere, nor where it comes from.

\section{Discussion}

Several mechanisms are proposed in order to explain our findings. (1) A reciprocal translocation between one chromosome $\mathrm{G}$ and another, probably large autosome, may be present, the translocation being genetically balanced. (2) Such a translocation might have occurred in a premeiotic cell, the segregation of which would have led to the trisomy of the translocated portion. (3) The donor chromosome being No. 21, the translocation would therefore be 'en tandem' with partial trisomy-21. From morphological and autoradiographic studies propositions 1 and 3 seem unlikely.

A few cases have been published with similar cytogentic findings. (a) Obviously genetical balanced translocation between one autosome and one chromosome of the $\mathrm{G}$ group has been studied in the parent and a propositus exhibiting mongolism (Pfeiffer, Laermann, and Heidtmann, 1967), or a syndrome of congenital malformations and maldevelopment (Mikkelsen et $a l ., 1968)$. In the first case trisomy-21 was present, in the second probably trisomy of a part of one chromosome of the $\mathrm{C}$ group. Lejeune et al. have seen a $2 / 22$ translocation through 3 generations: the propositus was a girl with features of Turner's syndrome resulting from concomitant monosomy $\mathrm{X}$. Neither duplication nor deficiency syndromes dependent on the translocation were seen.

(b) Sporadic cases with a large acrocentric chromosome replacing one $\mathrm{G}$ chromosome have been found in mongol patients (Zellweger, Mikamo, and Abbo, 1963; Lejeune et al., 1965; Robertson, Mellon, and Stewart, 1965; Richards, Stewart, and Sylvester, 1965). The interpretation of Lejeune et al. seems to be right. The heterozygotic state of this translocation was studied by Cohen and Davidson (1967) and Soudek, Laxová, and Adámek (1966, 1968).

(c) A translocation of a part of chromosome No. 1 on one $\mathrm{G}$ chromosome was found in a somatically and mentally retarded girl. Since the translocation was present in the child only, the significance of an elongation of the short arm of one $G$ chromosome in several members of the family was obscure. The propositus could be the carrier of a deficiencyduplication (Maganias et al., 1967).

(d) The case of Warkany and Soukup (1963) previously mentioned and the one here reported are more difficult to explair. From morphological 
Partial Trisomy in a Child with Features Suggesting Mongolism

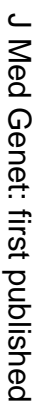

(a)
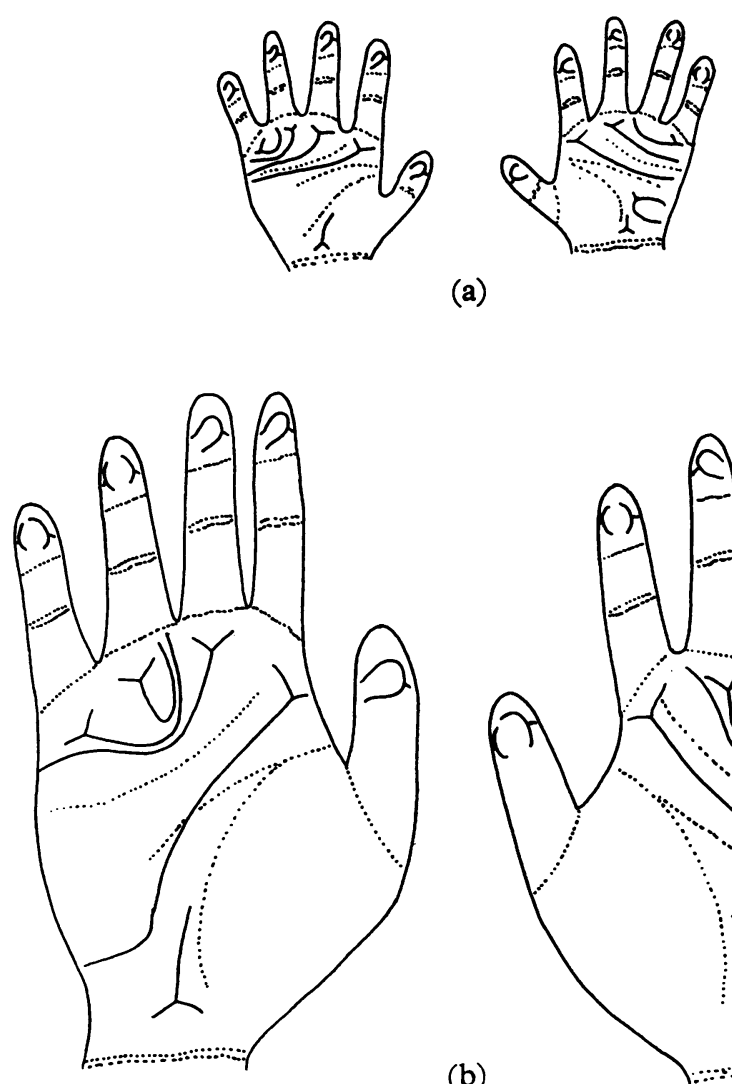

203

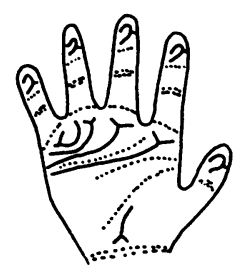

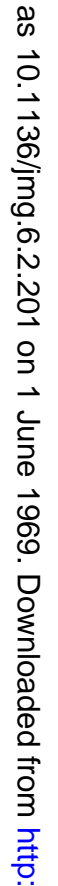

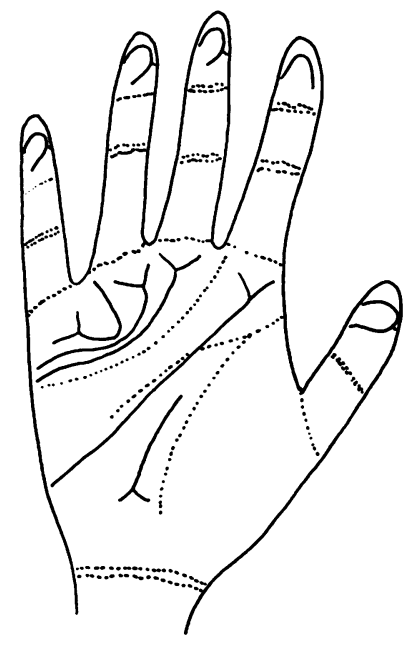

(b)

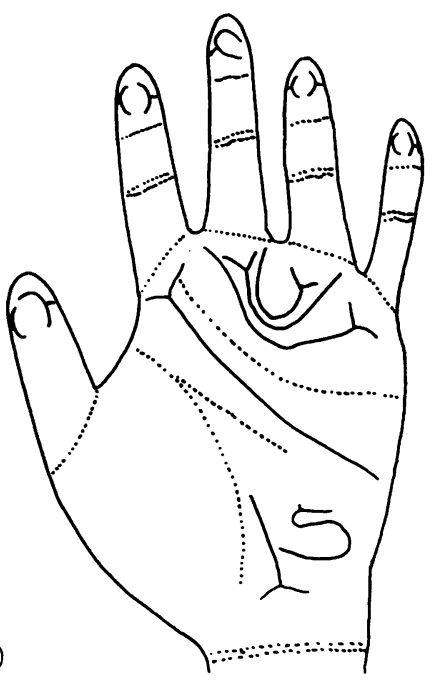

(c)

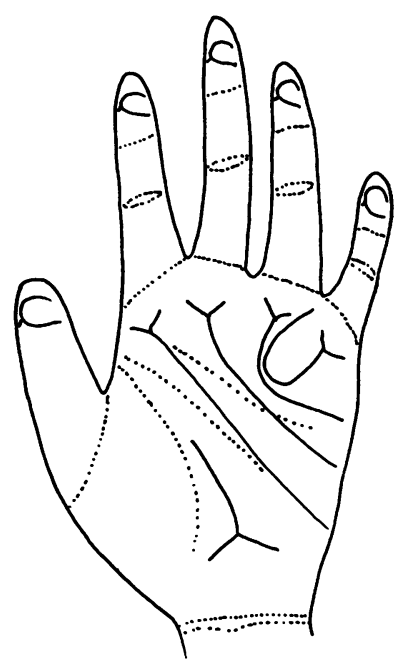

Fig. 3. Dermatoglyphs of the propositus (a), her father (b), and her mother (c). 
Fig. 4a. Karyotype of the propositus. The acrocentric extra chromosome can hardly be distinguished from the autosomes 13-15.

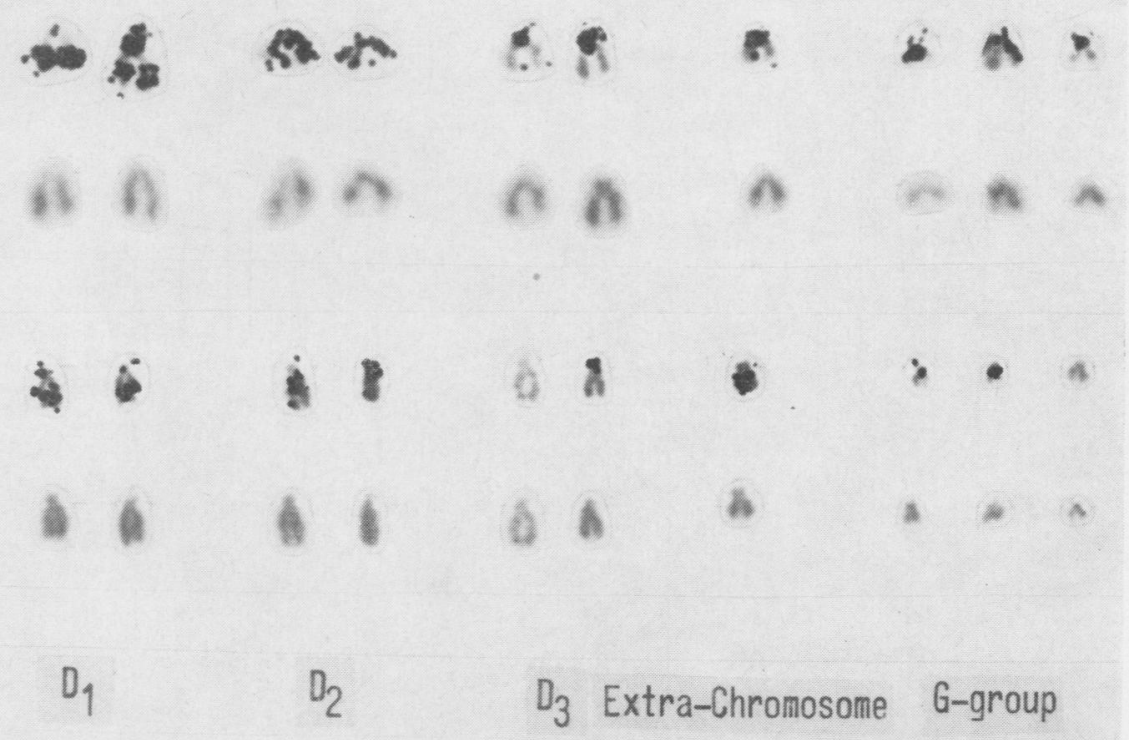

Fig. 4b. The labelling pattern of the acrocentric chromosomes of two cells serves to distinguish the chromosome but gives no evidence as to the origin of the duplicated portion. 
findings a partial trisomy seems to be present; the donor chromosome, however, remains undetected and is perhaps different in both cases. From the known cases of probable partial trisomy-21 one would expect several typical symptoms such as dermatoglyphic features or a low iliac index. 'Mongol' physiognomy only cannot support the hypothesis that a trisomy-21 underlies. Single stigmata in mongolism are not specific and have been observed in various chromosomal anomalies (Pfeiffer 1967).

\section{Summary}

Sporadic partial trisomy of a chromosome which could not be identified even by autoradiography was found in a girl with psychomotor retardation, hypoplasia of the toes and nails, and peculiar physiognomic traits which suggested mongolism.

Dr. H. K. Kumbnani is in receipt of a Post-doctoral fellowship from the Alexander-von-Humboldt-Stiftung. Cytogenetic studies were supported by a grant of the Deutsche Forschungsgemeinschaft to Dr. R. A. Pfeiffer. Autoradiography was performed in collaboration with Dr. Th. Büchner.

\section{REFERENCES}

Büchner, Th., Wilkens, A., and Pfeiffer, R. A. (1968). Autoradiographisches Markierungsmuster der Chromosomen Nr. 1, 2, 3, 4, 5, 13-15, 16 und Grad der Übereinstimmung der Homologen nach Einbau von H3-Thymidin während der späten S-Phase. Quanti- tative Untersuchungen an Zellen der Blutkultur. Klin. Wschr., 46, 187.

Cohen, M. M., and Davidson, R. G. (1967). Down's syndrome associated with a familial $(21 \mathrm{q}-; 22 \mathrm{q}+)$ translocations. Cytogenetics, 6, 321.

Lejeune, J., Berger, R., Vidal, O. R., and Rethore, M.-O. (1965). Un cas de translocation G-G en tandem. Ann. Génét., 8, 60 .

Maganias, N. H., Archambault, L., Becker, L., and Winnacker, J. L. (1967). A I/G translocation in a member of a kindred with a marker chromosome. Arch. intern. Med., 119, 297.

Mikkelsen, M., Mortensen, E., Skakkebaek, N. E., and Yssing, M. (1968). Familial reciprocal translocation between a C group (12 ?) chromosome and a late labelling G chromosome. Acta genet. (Basel), 18, 241.

Moorhead, P. S., Nowell, P. C., Mellman, W. J., Battips, D. M., and Hungerford, D. A. (1960). Chromosome preparations of leukocytes cultured from human peripheral blood. Exp. Cell Res., 20, 613.

Pfeiffer, R. A. (1967). Inborn autosomal disorders: The phenotype of autosomal aberrations. In Proc. Third International Congress of Human Genetics, Sept. 1966 in Chicago, p. 103. The Johns Hopkins Press, Baltimore.

, Laermann, J., and Heidtmann, H. L. (1967). Reziproke Translokation zwischen einem Chromosom Nr. 21 (G1) und einem Chromosom der Gruppe C (C6). Helv. paediat. Acta, 22, 558.

Richards, B. W., Stewart, A., and Sylvester, P. E. (1965). Reciprocal translocation and mosaicism in a mongol. f. ment. Defic. Res., 9, 118.

Robertson, J., Mellon, J. P., and Stewart, J. S. S. (1965). Down's syndrome with unusual karyotype and thyroid autoantibodies. ibid., 9, 157.

Soudek, D., Laxová, R., and Adámek, R. (1966). Development of translocation 21/22. Lancet, 2, 336.

,-- , and - (1968). Pericentric inversion in a family with a 21/22 translocation. Cytogenetics, 7, 108.

Warkany, J., and Soukup, S. W. (1963). A chromosomal abnormality in a girl with some features of Down's syndrome (mongolism). f. Pediat., 62, 890 .

Zellweger, H., Mikamo, K., and Abbo, G. (1963). An unusual translocation in a case of mongolism. ibid., 62, 225. 